\title{
Influence of the Tropical Atlantic Ocean's Sea Surface Temperature in the Eastern Northeast Brazil Precipitation
}

\author{
Ana Cleide Bezerra Amorim, Rosane Rodrigues Chaves, Cláudio Moisés Santos e Silva \\ Universidade Federal do Rio Grande do Norte (UFRN), Programa de Pós-Graduação em Ciências Climáticas \\ (PPGCC), Natal, Brasil \\ Email: anacleide23@gmail.com
}

Received 27 September 2014; revised 31 October 2014; accepted 19 November 2014

Copyright (C) 2014 by authors and Scientific Research Publishing Inc.

This work is licensed under the Creative Commons Attribution International License (CC BY).

http://creativecommons.org/licenses/by/4.0/

(c) (i) Open Access

\section{Abstract}

An analysis of the rainfall of the Eastern Northeast Brazil (ENEB) during the period from April to June and the processes of ocean-atmosphere interaction were performed during different episodes of Sea Surface Temperature (SST) inter-hemispheric gradient of Atlantic tropical (GRAD). For this, we used a dataset covering the 1981 to 2010 period, composed by: monthly data of accumulated precipitation of the Global Precipitation Climatology Project (GPCP); surface fluxes obtained from reanalysis of the National Center for Environmental Prediction (NCEP); vertically integrated moisture flux divergence of the global model of European Centre for Medium Range Forecasting (ECMWF) reanalysis; SST data from the NCEP. Seven GRAD_S (southward SST gradient in the intertropical Atlantic) and five GRAD_N (northward SST gradient in the intertropical Atlantic) were selected. When the South Atlantic Ocean is warmer, the oceanic and atmospheric conditions are favorable to higher monthly precipitation near to the ENEB. We also observed a pronounced moisture convergence over parts of the ENEB during both, GRAD_S and GRAD_N episodes. The weather phenomena that operates remotely amplifying or inhibiting the rain also helps the rainy season; however, it appears that the contribution was greater than the spatial distribution of rainfall intensity.

\section{Keywords}

Ocean-Atmosphere, Coastline, Heat Balance, Moisture Fluxes, Flux Divergence

\section{Introduction}

The fluxes of heat, momentum and moisture are very important for the development of atmospheric and oceanic

How to cite this paper: Amorim, A.C.B., et al. (2014) Influence of the Tropical Atlantic Ocean's Sea Surface Temperature in the Eastern Northeast Brazil Precipitation. Atmospheric and Climate Sciences, 4, 874-883. 
circulations; any significant variation in these fluxes directly affects the circulation and precipitation systems in a given region [1]. The pattern of Sea Surface Temperature Anomaly (SSTA) in the North and South Atlantic, which reflect the occurrence of precipitation anomalies in the Northeast of Brazil (NEB), shows the importance of coupling in the ocean-atmosphere interface. In this sense, the variability of Sea Surface Temperature (SST) causes changes in the pattern of atmospheric circulation and therefore, the behavior of the large scale weather systems responsible for the precipitation over Northern NEB [2] [3].

The NEB presents different types of climate, the annual precipitation range from $300 \mathrm{~mm}$ in semi-arid region to $2000 \mathrm{~mm}$ on the coast. The dynamic of the meteorological systems operating in the Northeast were reviewed by [4]. In Northern NEB (NNEB), the higher values of precipitation are due to the Atlantic Intertropical Convergence Zone (ITCZ), which has its climatologically position further South around $4^{\circ} \mathrm{S}$ in March and April, and further North around $10^{\circ} \mathrm{N}-14^{\circ} \mathrm{N}$ in August-September [5]. In the eastern (ENEB), region of interest in this study, the precipitation occurrence is modulated by easterly wave disturbance (EWD) [6]-[10] with maximum activity between May and July

Besides EWD, frontal systems moving from middle latitudes are also observed, especially in the Southern part of the NEB [11], as well as high level cyclonic vortices [12].

The interannual variability of NEB precipitation has been the focus of studies for the last decades. Thus, dry or rainy years have been related to inter annual variability associated with the El-Niño-Southern oscillation (ENSO) phenomena. In addition, the SST inter-hemispheric Gradient of Atlantic (GRAD) can influence the precipitation over the NEB, including intensifying or inhibiting the ENSO effects [13]. The simultaneous occurrence of these two phenomena has been investigated [2] [13]-[18]. In some cases, the influence of the Atlantic (mainly the South Atlantic Basin) in the NNEB precipitation is more relevant than the SST of Pacific [16]. The variability in the South Atlantic Ocean (SAO) has been under discussion, since no relation with the North Atlantic Oscillation (NAO) and only a weak relation with ENSO have been reported by some authors [19].

Most of the studies highlight the NNEB in relation to the adjacent oceans analyzing the ITCZ, weather system that determines the rainy season of this region. However, there is an increasing interest in understanding the dynamic of precipitation occurrence in the ENEB region [10]-[20] [21], since it is in this region that most of the NEB population is concentrated and in where the most extreme precipitation events occur in the region [22]. In this study the main objective is to analyze the precipitation in ENEB from April to June and the processes of ocean-atmosphere interaction, mainly the episodes of GRAD_S.

One of the motivations to study the Atlantic GRAD_S is seen in [23], which identified through analysis variance (ANOVA) significant evidence concerning the different phases of the tropical Atlantic, in relation of the precipitation in ENEB at a significance level of 5\%, mainly in GRAD_S that was associated with precipitation excess, unlike other phases that showed no significant variability. However, in the study of [23] and the adjusted ANOVA model was used specific temporal rainfall series in ENEB. In this study we propose to verify the spatial distribution of precipitation across the Eastern region that also showed significant volumes during episodes of GRAD_S, as well as verifying if atmospheric and oceanic conditions favored the excess of precipitation diagnosed by [23].

\section{Data and Methodology}

\subsection{Data}

Monthly precipitation data were used from 1981 to 2010, from the Global Precipitation Climatology Project (GPCP) of the World Climate Research Programme (WCRP), which aim to quantify the distribution of global precipitation [24]. The GPCP uses information from polar orbit satellites, geostationary and observed data. Finally, the dataset is disposed in a regular grid with a spacing of $0.5^{\circ} \times 0.5^{\circ}$. The period from 1981 to 2010 was chosen for representing the most updated climatological series for precipitation.

The fluxes fields at surface were obtained from the reanalysis [25] of National Center for Environmental Prediction (NCEP). We used the monthly averages, which are provided in a regular grid of $2.5^{\circ} \times 2.5^{\circ}$, for the period of 1982-2012.

The fields of vertically integrated moisture fluxes are from reanalyzes of the global European Centre for Medium-Range Weather Forecasts Interim Re-Analysis (ERA-Interim) model [26], also for the period from 1982 to 2012, disposed in a grid of $1.5^{\circ} \times 1.5^{\circ}$ latitude by longitude.

The SST data were obtained from NCEP [27] for areas located North $\left(5^{\circ} \mathrm{N}-20^{\circ} \mathrm{N}, 60^{\circ} \mathrm{W}-30^{\circ} \mathrm{W}\right)$ and South 
$\left(0^{\circ} \mathrm{S}-20^{\circ} \mathrm{S}, 30^{\circ} \mathrm{W}-10^{\circ} \mathrm{E}\right)$ of the Tropical Atlantic (http://www.cpc.ncep.noaa.gov/data/indices/). Figure 1 show the areas of study, which will be highlighted along the results.

The ENEB shows around $60 \%$ of annual precipitation concentrated in the period from April to June, [28]. In Figure 2, it is possible to observe the monthly time series of ENEB precipitation of GCPC, for the period from 1981 to 2011. The GCPC data are in accordance with [28], with 56.9\% of the annual rainfall in the region occurs in April-May-June (AMJ) quarter.
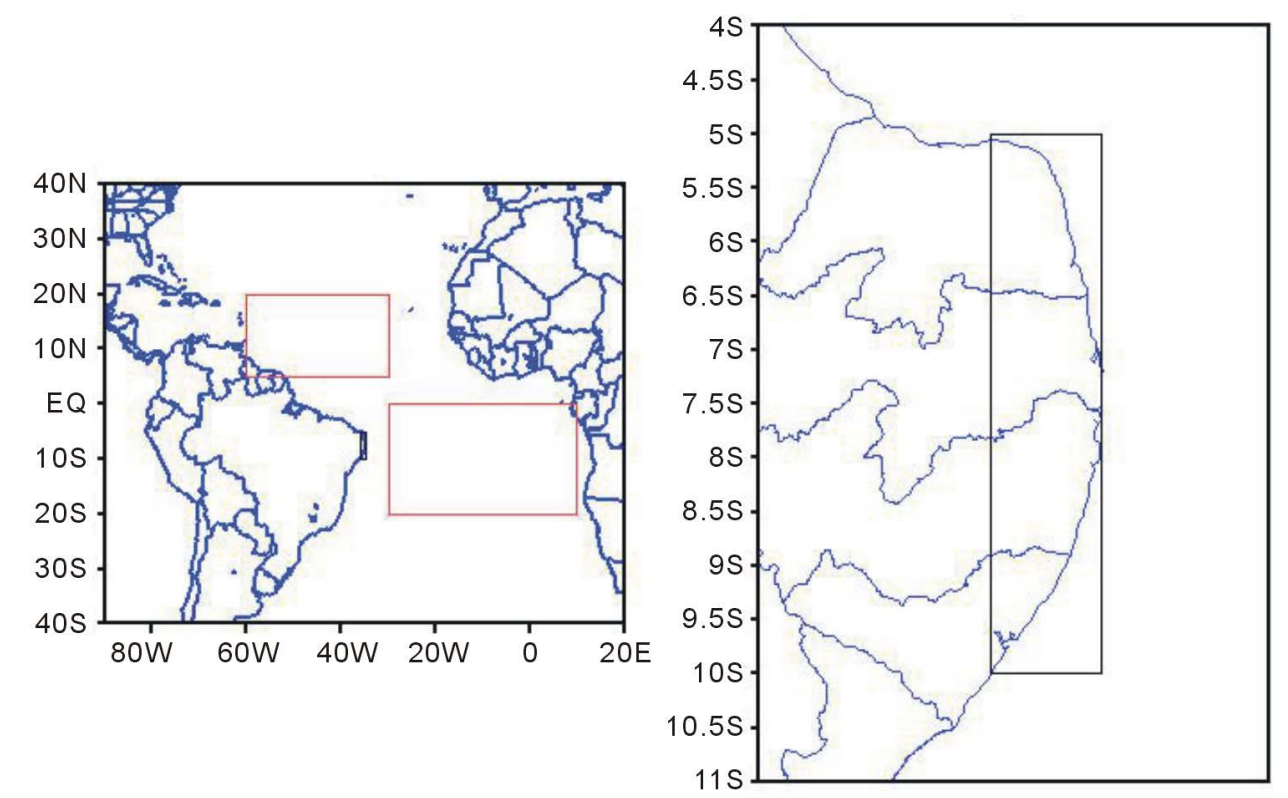

(a)

(b)

Figure 1. Areas of study. On the left (a) it shows the Atlantic region, and on the right (b), the Eastern coast of the NEB.

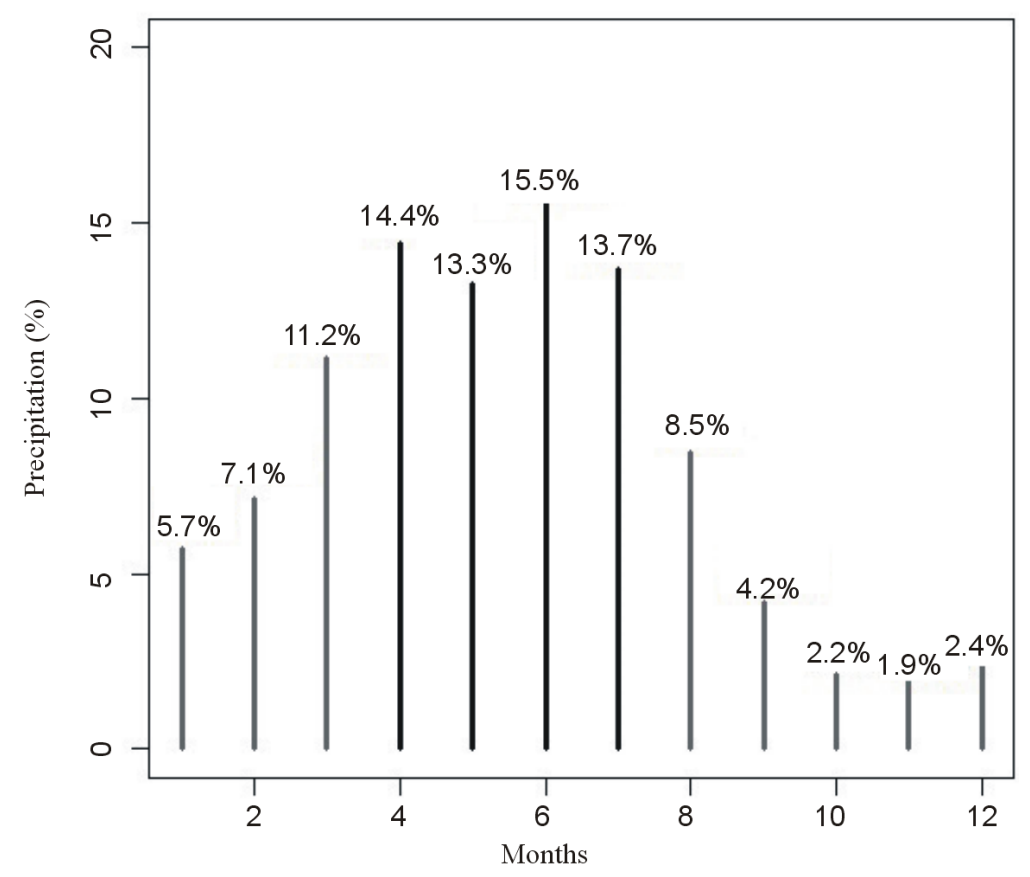

Figure 2. Percentage of monthly precipitation in relation to the annual total for ENEB, with data from GCPC. 


\subsection{Methodology}

\subsubsection{Selection of Anomalous Years of the Atlantic Ocean}

In order to identify the anomalous years in the Atlantic Ocean we used the same criterion applied by [13]. They identified years of GRAD_N Atlantic those that showed simultaneously positive anomalies of SST in the North Atlantic and negative anomalies in the South Atlantic during the months from February to April (FMA). For GRAD_S, the anomalies of SST for the south are positive and negative to the North. Besides the FMA months, therefore GRAD manifests from February, but establishes in MAM (March to May), [13]. The months May and June are also analyzed regarding the presence of GRAD_S, due being rainy months of ENEB.

From this criterion, GRAD_S episodes were 1984, 1986, 1989, 1991, 1994, 2008 and 2009, while the GRAD_N episodes were 1983, 1992, 1997, 2004 and 2005. From these, the composites of AMJ periods of precipitation anomalies were calculated, as well as the total heat flux at the surface, the flux of latent and sensitive heat, and the divergence for both episodes, GRAD_S and GRAD_N.

\subsubsection{Heat Balance on the Surface}

The heat flux at surface represents how much energy coming from the Sun (shortwave) was partitioned among the sensible and latent flux, and the part that returned to space (long waves), then the balance was calculated by the Equation (1) as suggest by [19]:

$$
H t=Q S+Q N+L E+S H
$$

where: $Q S$ is the short wave incident radiation; $Q N$ is the long wave radiation emanating from the surface; LE is the latent heat flux by the surface due to the evaporation and $S H$ is the sensible heat flux. The units are $\mathrm{W} \cdot \mathrm{m}^{-2}$.

The Moisture Fluxes was evaluated between the surface and the $700 \mathrm{hPa}$ layer.

$$
\begin{aligned}
& Q_{t}=\frac{1}{g} \int_{p_{0}}^{p_{1}} q V d p \\
& Q_{\lambda}=\frac{1}{g} \int_{p_{0}}^{p_{1}} q u d p ; Q_{\varphi}=\frac{1}{g} \int_{p_{0}}^{p_{1}} q v d p \Rightarrow Q_{t}=Q_{\lambda} i+Q_{\varphi} j
\end{aligned}
$$

where: $Q_{t}$-total moisture flux; $g$ - the acceleration of gravity $\left(\approx 9.8 \mathrm{~m} / \mathrm{s}^{2}\right) ; q$-specific humidity; $p$ —pressure; $V$ is the magnitude of the wind; $p_{1}$ and $p_{0}$ represent the pressure at $700 \mathrm{hPa}$ and the surface, respectively [29].

The moisture flux divergence $\left(\mathrm{kg} \cdot \mathrm{m}^{-2} \mathrm{~s}^{-1}\right)$ will be evaluated by the Equation:

$$
\nabla \cdot Q_{t}=\frac{\partial Q_{\lambda}}{\partial x}+\frac{\partial Q_{\varphi}}{\partial y}
$$

The moisture flux was calculated by multiplying the average value of a by the area, that is in $\mathrm{kg} \cdot \mathrm{s}^{-1}$

$$
\oint \vec{Q} \cdot \vec{n} d L=\iint \nabla \cdot \vec{Q}{ }_{t} d A=\langle\nabla \cdot \vec{Q}\rangle d A=\langle\nabla \cdot \vec{Q}\rangle A
$$

where: $\vec{n}$ is the normal vector to the vertical faces; $d L$ is the lateral boundary length, described by the projection of the vertical faces of the area, in the horizontal plane; $\mathrm{A}$ is the area of $5^{\circ} \times 1.2^{\circ}$ latitude and longitude $\left(5^{\circ} \mathrm{S}\right.$ $\left.-10^{\circ} \mathrm{S} ; 36^{\circ} \mathrm{W}-34.8^{\circ} \mathrm{W}\right) ;\langle\rangle$ is the average in area $A$.

\section{Result and Discussion}

\subsection{Anomalies of Precipitation}

During the years of Tropical Atlantic GRAD_S, the ENEB showed excess of precipitation in relation to the climatology, except for the years 1991 and 2008, which showed rainfall deficit in the North and South coast, respectively. The year 1991 presented above the normal rainfall patterns for AMJ, only in the coast of Pernambuco, south of Sergipe and northern and eastern Bahia. In 2008, the precipitation excesses were more evident compared to the ones observed in 1991. However, most part of the states of Bahia, Alagoas and Sergipe, east of Pernambuco and Paraíba also registered deficit of precipitation. 
The variability in precipitation over the NEB is influenced by the Atlantic and Pacific Oceans, studies (e.g., [30]) showed this influence is mainly in GRAD area, although [17] had shown that simultaneous event of ENSO and significant SSTAs in the Atlantic contributed to increase or decrease the anomalies of precipitation. The SST anomalies of the same sign in ATS and eastern Pacific decreased the intensity of precipitation in NEB. Since 1991 was the year of strong El-Niño [31], and its can explain the negative anomalies of precipitation in this episode (Figure not shown) in most part of NEB. During the 1991 episode, the water vapor given by the ocean near the east coast of Brazil was lower compared to the other years studied, not supplying the atmosphere with water vapor and therefore inhibiting the precipitation in some areas of the region.

Figure 3 shows indeed rainfall excess during episodes of GRAD_S, as well as FMA in northern NEB. Despite ITCZ remaining in climatologically position further south during the episodes, contributing for the total rainfall at the beginning of ENEB rainy season (more precisely in the months of April and May), the easterly wave disturbances are also responsible for the quantity of rain until August, when ITCZ is already in a further North position. The EWD that possibly reached the Eastern region were strengthened to get closer to the coast. The oceanic region next to the east coast of the NEB on average, show favorable conditions for the occurrence of above the normal rainfall patterns for the period.

\subsection{Heat Balance on the Surface}

The heat balance on the surface involves incident shortwave radiation, long wave radiation emitted, latent and sensible heat, the sum of these energies precisely represents exchanges of energy in the ocean-atmosphere interface [19]. However, in this study, it will highlight the sum of the energies and latent energy.

During the GRAD_S an abnormal heat is generally observed in most part of the southern tropical Atlantic basin. This behavior represents more thermal energy being transferred to the atmosphere as well as more water vapor being removed from the ocean. Once the wind field shows favorable conditions, this humidity may feed the systems that cause precipitation in the region in this period, such as the wave easterly disturbances, which are more usual during the AMJ in ENEB.

In the oceanic region next to the east of the NEB, a negative balance of heat on the surface can be observed, except for the year of 2008. These conditions allow us to state that the oceanic surface layer next to the coast

(a)

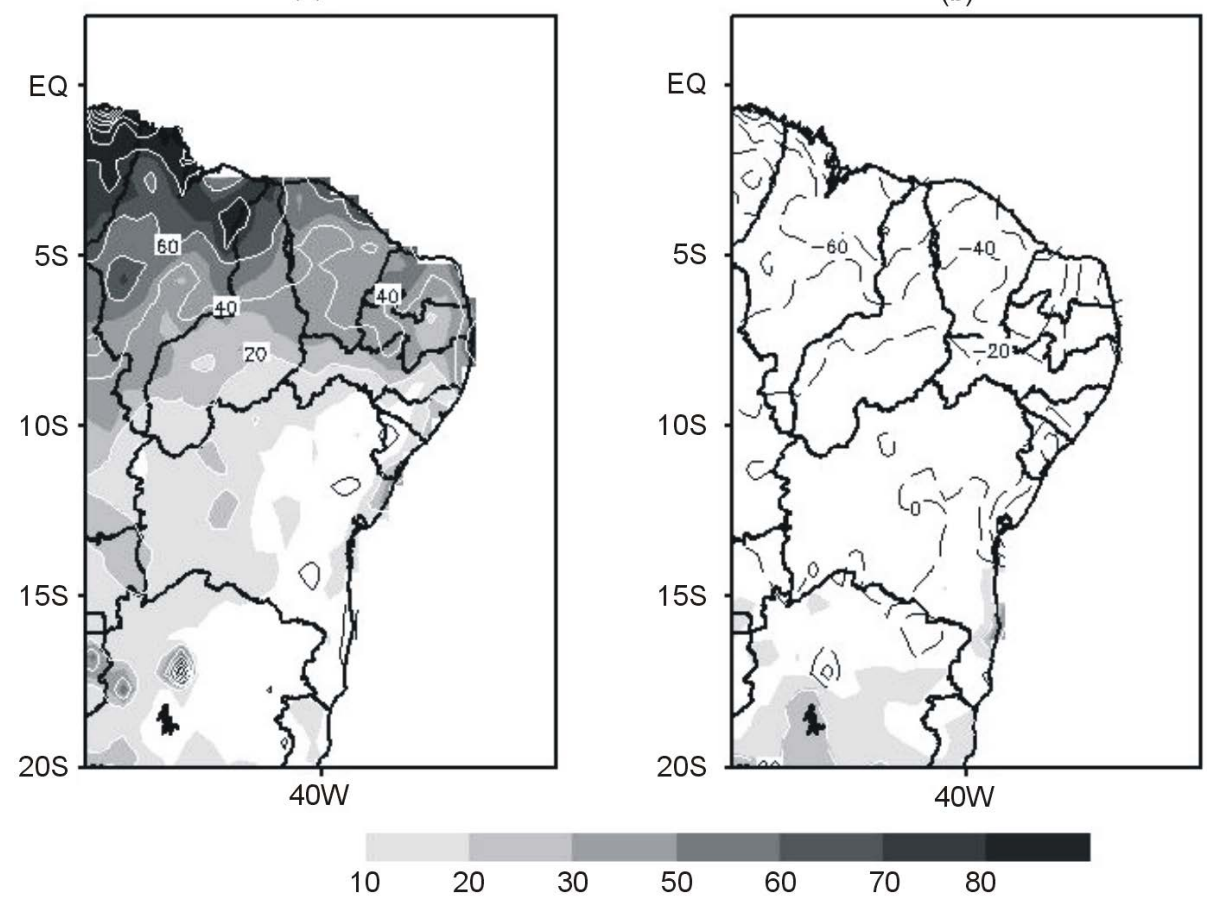

Figure 3. Standard precipitation anomalies in a) GRAD_S and b) GRAD_N episodes in NEB. Negative deviations (positive) of precipitation are represented by dashed lines (grayscale). 
remained, on average, warmer than normal during the trimester, nourishing of moisture EWD that reached the coast during the selected years.

Some regions with surplus of heat on the surface are observed between $5^{\circ} \mathrm{S}-10^{\circ} \mathrm{S}$ and $0^{\circ} \mathrm{W}-25^{\circ} \mathrm{W}$ over the Atlantic are highlighted when the episodes individually verified (Figure not shown), these small areas can be associated with the easterly waves, the persistence of events during the trimester may reflect to abnormality on these regions.

Figure 4, a negative balance of heat layer is observed between the equator and $10^{\circ} \mathrm{N}$, this region of strong latent heat release is a reflection of the presence of the ITCZ. During the AMJ period, this system is displaced to the Hemisphere of Summer depending on the weather. However, in years of GRAD_S, Figure 4(a) (GRAD_N, Figure 4(b)), studies have reported that the ITCZ remains longer in its position further south (north) influencing the rainy season of the North and Northeast region of Brazil. However, the remaining further south influences the Northern sector of ENEB at the beginning of rainy season, more precisely in April. In the other months (May and June) precipitation has occurred, mainly by EWD and remnants of frontal systems.

The anomalies of latent heat (Figure 5) next to the ENEB also agree with balance of power debated in Figure 4; coastal strip showed anomalies of latent energy below (above) the normal during the rainy seasons of year GRAD_S (GRAD_N) of Tropical Atlantic. Otherwise, over the continental region, areas with positive (negative) anomalies of latent energy, showing that the atmosphere lost more (less) energy than normal through the release of latent heat of condensation of water vapor as verified in the analysis of precipitation occurrence above (below) normal over the continent during episodes of GRAD_S (GRAD_N), Figure 3(a) (Figure 3(b)). In 1991 and 2008, negative anomalies of latent heat were observed, however they were seen in the North coast and far from ENEB coast, respectively.

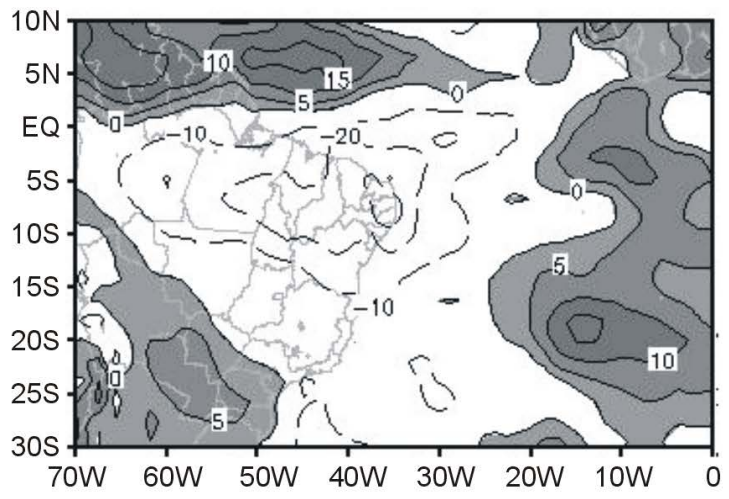

(a)

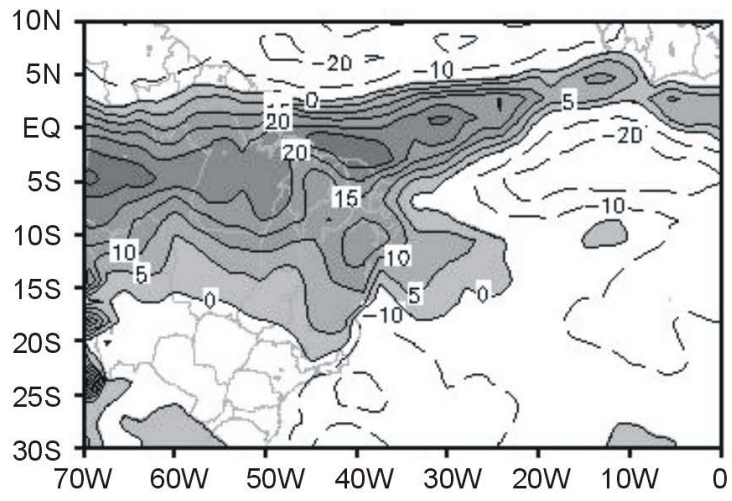

(b)

Figure 4. Total heat flux anomalies for the years of a) GRAD_S and b) GRAD_N of Tropical Atlantic in W· $\mathrm{m}^{-2}$. Negative deviation (positive) is with dashed lines and grayscale Gray (continuous line).

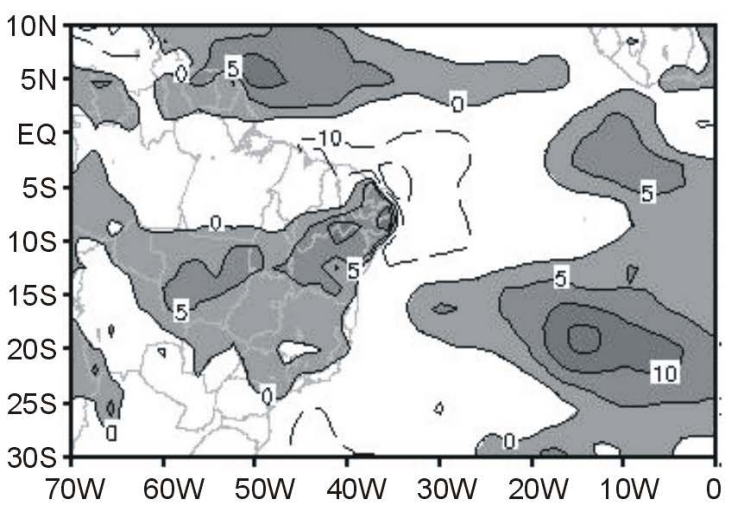

(a)

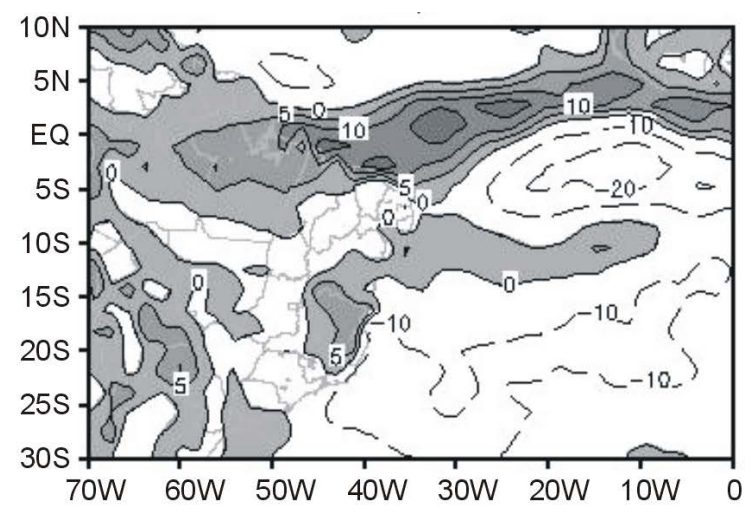

(b)

Figure 5. Anomaly of latent heat flux in the years of a) GRAD_S and b) GRAD_N of Tropical Atlantic in the unity $\mathrm{W} \cdot \mathrm{m}^{-2}$. Negative deviations (positive) are with dashed lines and grayscale (continuous line). 


\subsection{Moisture Flux Vertically Integrated}

The layer between the surface and $700 \mathrm{hPa}$ has the most part of humidity from the air in the atmosphere, diminishing considerably with height. Figure 6 shows water vapor anomalies and respective anomalous flux at lower levels of the atmosphere. The prevalence of abnormalities in ENEB flux is from Northeast/North (southeast/south) during the GRAD_S (GRAD_N). This behavior is reflected in the region of Hadley circulation confluence displaced to the south (North) of the Equator, favoring (disfavoring) appropriate conditions for precipitation over the region. Similar results were observed by [32] for 1985 and for the FMA period. In addition, the pattern GRAD_S (GRAD_N) provides more (less) water vapor to the atmosphere, positive (negative) anomalies in all NEB are observed.

\subsection{Divergence Vertically Integrated of Moisture Flux}

The convergence at low levels, for continuous waves, generates upward vertical movements, favoring the development of clouds and, consequently, the given precipitation due to the availability of moisture. However, the GRAD_S and GRAD_N episodes enhance or inhibit these dynamic effects in the region, making the rainy periods more or less intense [32]

The Southern portion of ENEB in both patterns of the tropical Atlantic is observed the divergence in the first layers of the atmosphere. The further North portion of the region experiences changes as in the intensity as the location of divergence, it is observed that it is intense on the coast of Bahia in both patterns, however in GRAD_ $\mathrm{N}$ the values are more intense. During the GRAD_S, the region that shows convergence of moisture flux covers the entire range of $9^{\circ} \mathrm{S}$ toward the equator over the NEB. When the pattern is contrary, the region of convergence decreases slightly further North, mainly on the coast.

Despite the North region and the east part of the NEB provide moisture convergence (Figure 6) in both patterns of SST of the Atlantic (GRAD_S and GRAD_N), the occurrence of precipitation depends on the availability of water vapor (Figure 5) in the atmosphere, and this behavior was observed during the GRAD_S (GRAD_ $\mathrm{N}$ ), where positive anomalies (negative) of water vapor were observed in most part of NEB.

Finally, Figure 7 provides the calculated moisture flux, which was multiplied by the divergence average value by the ENEB area. The convergence values explain the precipitation excesses that on average are observed in the coast of ENEB, mainly during episodes of GRAD_S $\left(-162.6 \times 10^{-9} \mathrm{~kg} \cdot \mathrm{s}^{-1}\right)$, showing importation of relative humidity above $50 \%$ of the value shown in GRAD_N $\left(-58.2 \times 10^{-9} \mathrm{~kg} \cdot \mathrm{s}^{-1}\right)$. The water vapor found in the first

(a)

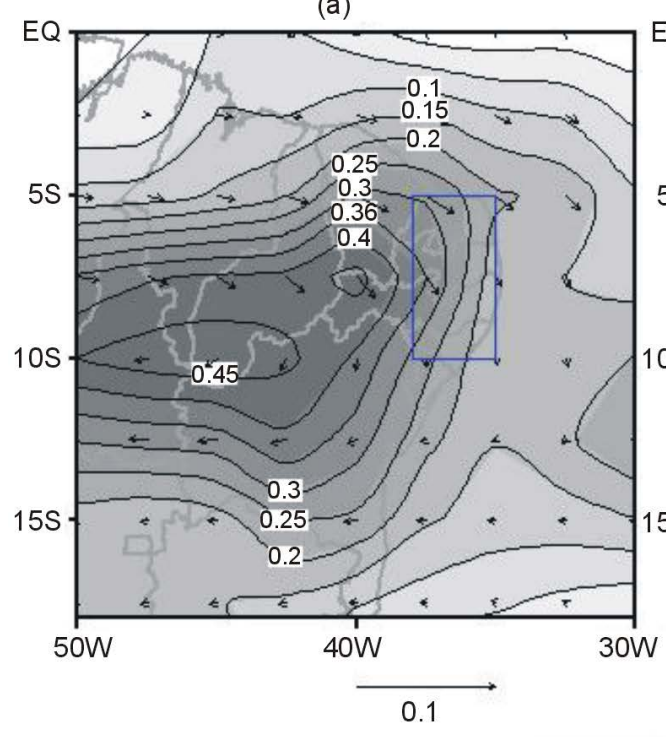

(b)

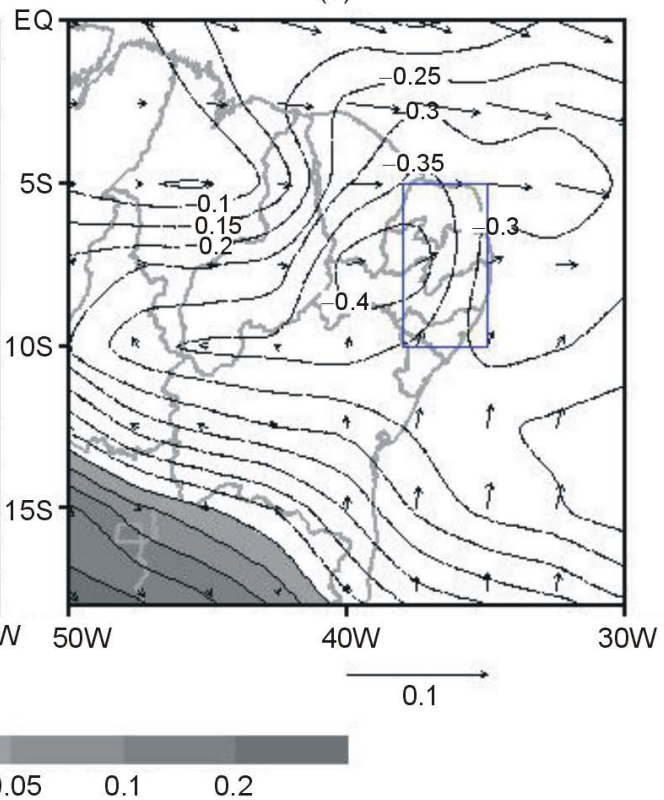

Figure 6. Flux anomalies vertically integrated between the surface and $700 \mathrm{hPa}$ of a) GRAD_S and b) GRAD_N episodes. 


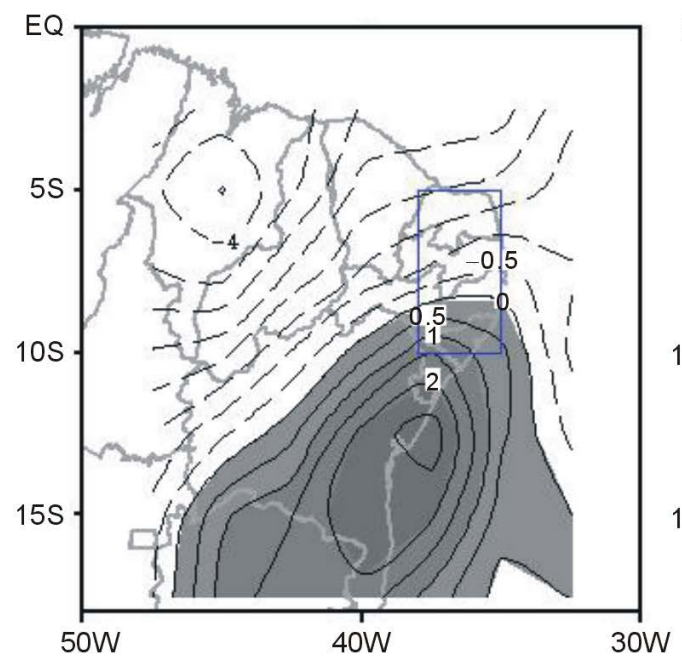

(a)

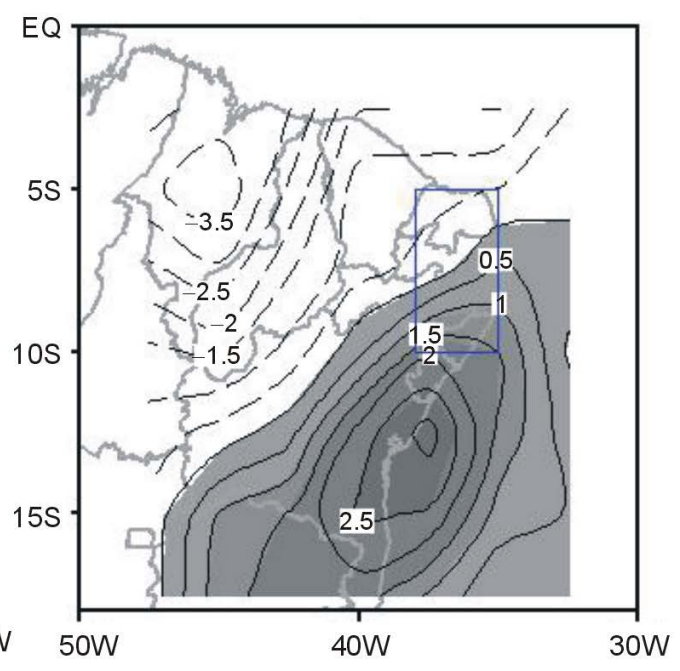

(b)

Figure 7. Moisture flux divergence vertically integrated $\left(10^{9} \mathrm{~kg} \cdot \mathrm{s}^{-1}\right)$ during episodes of a) GRAD_S and b) GRAD_N. The positive (negative) values show divergence (convergence) of moisture and they are highlighted in shades of gray (in dashed line).

layers of the atmosphere in ENEB is imported from the oceanic region as rule. Despite the wave adjustment not to be carried out in this study, the results were satisfactory to explain the precipitation anomalies above normal during the GRAD_S in the region ENEB, during the rainy season.

\section{Conclusions}

The results showed the importance of ocean-atmosphere interaction in the South Atlantic for precipitation in ENEB. It can be seen that small variations in SST cause strong influences on the flux between the ocean and atmosphere causing impact on weather systems that operate in the region during rainy season.

During episodes where the South Atlantic Ocean was warmer, oceanic and atmospheric favorable conditions were observed, favorable to change in the distribution and volume of precipitation, and inclusive next to the east coast, which supposedly intensified the weather systems that reached the coast.

In this observational study, it can be concluded that the ocean-atmosphere interaction present in the Tropical South Atlantic favors the deviations in rainfall in ENEB. The weather phenomena that operates remotely amplifying or inhibiting the rain also helps the rainy season; however, it appears that the contribution is greater than the spatial distribution of rainfall intensity. In 1991 and 2008 episodes (El Niño and La Niña, respectively), years in which the Pacific Ocean showed the SST anomalies, above normal precipitation were seen on the east coast of NEB; however only the spatial distribution of these precipitation anomalies was affected.

We can also observe that the moisture convergence over the ENEB region in both Atlantic SST patterns (GRAD_S and GRAD_N). However, the occurrence of precipitation depends on the availability of water vapor, situation that depends on the conditions of the oceans, the main source of moisture for the NEB region.

\section{Acknowledgements}

To the Coordenacão de Aperfeiçoamento de Pessoal de Nível Superior (CAPES) by doctoral scholarship of the of Planos de Reestruturação e Expansão das Universidades Federais (Reuni), the first author, A. C. B. Amorim.

\section{References}

[1] Doyle, J.D. (2002) Coupled Atmosphere-Ocean Wave Simulations under High Wind Conditions. Monthly Weather Review, 130, 3087-3099. http://dx.doi.org/10.1175/1520-0493(2002)130<3087:CAOWSU>2.0.CO;2

[2] Moura, A.D. and Shukla, J. (1981) On the Dynamics of Droughts in Northeast Brazil: Observations, Theory and Numerical Experiments with a General Circulation Model. Journal of the Atmospherical Sciences, 38, 2653-2675. http://dx.doi.org/10.1175/1520-0469(1981)038<2653:OTDODI $>2.0 . C O ; 2$ 
[3] Souza, E.B. and Nobre, P. (1998) Uma revisão do Padrão Dipolo no Atlântico Tropical. Revista Brasileira de Meteorologia, 13, 31-44.

[4] Molion, L.C.B. and Bernardo, S.O. (2002) Uma revisão da dinâmica das chuvas no nordeste brasileiro. Revista Brasileira de Meteorologia, 17, 1-10.

[5] Souza, P.E. and Cavalcanti, I.F.A (2009) Atmospheric Centres of Action Associated with the Atlantic ITCZ Position. International Journal of Climatology, 29, 2091-2105. http://dx.doi.org/10.1002/joc.1823

[6] Ramos, R.P.L. (1975) Precipitation Characteristics in the Northeast Brazil Dry Region. Journal of Geophysical Research, 80, 1665-1678. http://dx.doi.org/10.1029/JC080i012p01665

[7] Yamazaki, Y. and Rao, V.B. (1977) Tropical Cloudiness over the South Atlantic Ocean. Journal of the Meteorological Society of Japan, 55, 205-207.

[8] Chou, S.C. (1990) Análise de distúrbios ondulatórios de leste sobre o oceano atlântico equatorial sul. Dissertation, Instituto Nacional de Pesquisas Espaciais, São José dos Campos.

[9] Torres, R.R. and Ferreira, N.J. (2011) Case Studies of Easterly Wave Disturbances over Northeast Brazil Using the Eta Model. Weather and Forecast, 26, 225-235. http://dx.doi.org/10.1175/2010WAF2222425.1

[10] Kouadio, Y.K., Servain, J., Machado, L.T. and Lentini, C.A.D (2012) Heavy Rainfall Episodes in the Eastern Northeast Brazil Linked to Large-Scale Ocean-Atmosphere Conditions in the Tropical Atlantic. Advances in Meteorology, 2012, 1-16. http://dx.doi.org/10.1155/2012/369567

[11] Kousky, V.E. (1979) Frontal influence on Northeast Brazil. Monthly Weather Review, 107, 1140-1153. http://dx.doi.org/10.1175/1520-0493(1979)107<1140:FIONB>2.0.CO;2

[12] Mishra, S.K., Rao, V.B. and Franchito, S.H. (2007) Genesis of the Northeast Brazil Upper-Tropospheric Cyclonic Vortex: A Primitive Equation Barotropic Instability Study. Journal of the Atmospherical Sciences, 64, 1379-1392. http://dx.doi.org/10.1175/JAS3893.1

[13] Souza, E.B., Kayano, M.T. and Ambrizzi, T. (2005) Intraseasonal and Submonthly Variability within Autmn Rainy Regime over the Eastern Amazon/Northeast Brazil and Associated Mechanisms. Theoretical and Applied Climatology, 81, 177-191. http://dx.doi.org/10.1007/s00704-004-0081-4

[14] Hastenrath, S. and Heller, L. (1977) Dynamcs of Climatic Hazards in Northeast Brazil. Quarterly Journal of the Royal Meteorological Society, 107, 77-92. http://dx.doi.org/10.1002/qi.49710343505

[15] Saravanan, R. and Chang, P. (2000) Interaction between Tropical Atlantic variability and El Ni-o-Southern Oscillation, Journal of Climate, 13, 2177-2194. http://dx.doi.org/10.1175/1520-0442(2000)013<2177:IBTAVA>2.0.CO;2

[16] Andreoly, R.V. and Kayano, M.T. (2006) Tropical Pacific and South Atlantic Effects on Rainfall Variability over Northeastern Brazil. International Journal Climatology, 26, 1895-1912. http://dx.doi.org/10.1002/joc.1341

[17] Andreoli, R.V. and Kayano, M.T. (2007) A importância relativa do Atlântico Tropical Sul e Pacífico leste na variabilidade de precipitação do Nordeste do Brasil. Revista Brasileira de Meteorologia, 22, 63-74. http://dx.doi.org/10.1590/S0102-77862007000100007

[18] Kayano, M.T., Oliveira, C.P. and Andreoli, R.V. (2009) Interannual Relations between South American Rainfall and Tropical Sea Surface Temperature Anomalies before and after 1976. International Journal of Climatology, 29, 14391448. http://dx.doi.org/10.1002/joc.1824

[19] Sterl, A. and Hazeleger, W. (2003) Coupled Variability and Air-Sea Interaction in the South Atlantic Ocean. Climate Dynamics, 21, 559-571. http://dx.doi.org/10.1007/s00382-003-0348-y

[20] Oliveira, P.T., Lima, K.C. and Silva, C.M.S. (2013) Synoptic Environment Associated with Heavy Rainfall Events on the Coastland of Northeast Brazil. Advances in Geosciences, 35, 73-78. http://dx.doi.org/10.5194/adgeo-35-73-2013

[21] Silva, C.M.S., Silva, A., Oliveira, P. and Lima, K.C. (2014) Dynamical Downscaling of the Precipitation in Northeast Brazil with a Regional Climate Model during Contrasting Years. Atmospheric Science Letters, 15, 50-57. http://dx.doi.org/10.1002/asl2.468

[22] Grimm, A.M. and Tedeschi, R.G. (2009) Enso and Extreme Rainfall Events in South America. Journal of Climate, 22, 1589-1609. http://dx.doi.org/10.1175/2008JCLI2429.1

[23] Amorim, A.C.B, Chaves, R.R. and Spyrides, M.H.C. (2012) Precipitação no leste do nordeste brasileiro (lneb) e episódios anômalos no oceano atlântico tropical. 17th Congresso Brasileiro De Meteorologia, Gramado, Anais XVII do Congresso brasileiro de meteorologia, September 2012, Gramado.

[24] Huffman, G., Adler, R.F., Arkin, P., Chang, A., Ferraro, R., Gruber, A., et al. (1997) The Global Precipitation Climatology Project (GPCP) Combined Precipitation Dataset. Bulletin of the American Meteorological Society, 78, 5-20. http://dx.doi.org/10.1175/1520-0477(1997)078<0005:TGPCPG>2.0.CO;2

[25] Kalnay, E., Kanamitsu, M., Kistler, R., Collins, W., Deaven, D., Gandin, L., et al. (1996) The NCEP/NCAR 40-Year 
Reanalysis Project. Bulletin of the American Meteorological Society, 77, 437-471. http://dx.doi.org/10.1175/1520-0477(1996)077<0437:TNYRP>2.0.CO;2

[26] Dee, D.P., Uppala, S.M., Simmons, A.J., Berrisford, P., Poli, P., Kobayashi, S., et al. (2010) The ERA-Interim Reanalysis: Configuration and Performance of the Data Assimilation System. Quarterly Journal of the Royal Meteorological Society, 137, 553-597. http://dx.doi.org/10.1002/qj.828

[27] Smith, T.M. and Reynolds, R.W. (1998) A High-Resolution Global Sea Surface Temperature Climatology for the 1961-90 Base Period. Journal of Climate, 11, 3320-3323. http://dx.doi.org/10.1175/1520-0442(1998)011<3320:AHRGSS>2.0.CO;2

[28] Rao, V.B., de Lima, M.C. and Franchito, S.H. (1993) Seasonal and Interannual Variations of Rainfall over Eastern Northeast Brazil. Journal of Climate, 6, 1754-1763. http://dx.doi.org/10.1175/1520-0442(1993)006<1754:SAIVOR>2.0.CO;2

[29] Rao, V.B., Chapa, S.R. and Franchito, S.H. (1999) Decadal Variation of Atmosphere-Ocean Interaction in the Tropical Atlantic and Its Relationship to the Northeast-Brazil Rainfall. Journal of the Meteorological Society of Japan, 77, 6375.

[30] Moura, G.B.A., Aragão, J.O.R., Melo, J.S.P., Silva, A.P.N., Giongo, P.R. and Lacerda, F.F. (2009) Relação entre a precipitação do leste do Nordeste do Brasil e a temperatura dos oceanos. Revista Brasileira de Engenharia Agrícola e Ambiental, 13, 462-469. http://dx.doi.org/10.1590/S1415-43662009000400014

[31] Centro de Previsão de Tempo e Estudos Climáticos (CPTEC) (2012) El-Niño e La-Niña. http://enos.cptec.inpe.br/

[32] Bezerra, A.C.N. (2006) Aspectos da circulação atmosférica de grande escala sobre o norte e nordeste do Brasil relacionados com a temperatura da superfície do mar. Dissertation, Universidade de Federal de Campina Grande, Centro de Tecnologia e Recursos Naturais-Unidade Acadêmica de Ciências Atmosféricas, Campina Grande. 
Scientific Research Publishing (SCIRP) is one of the largest Open Access journal publishers. It is currently publishing more than 200 open access, online, peer-reviewed journals covering a wide range of academic disciplines. SCIRP serves the worldwide academic communities and contributes to the progress and application of science with its publication.

Other selected journals from SCIRP are listed as below. Submit your manuscript to us via either submit@scirp.org or Online Submission Portal.
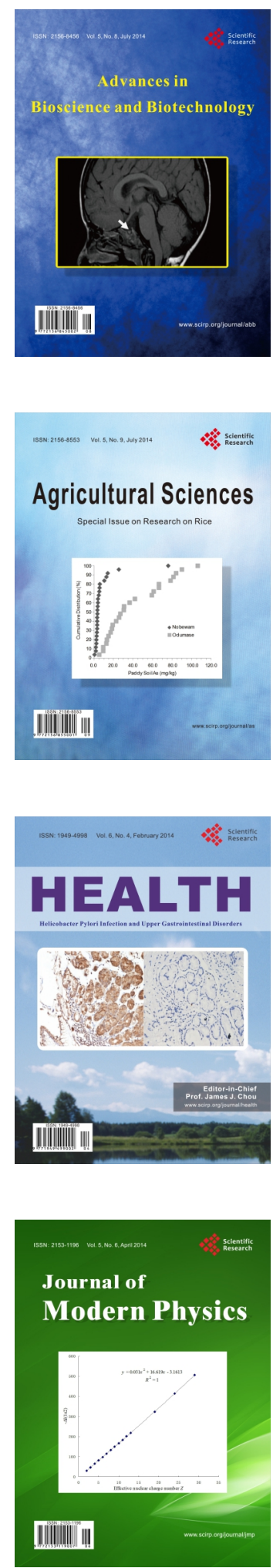
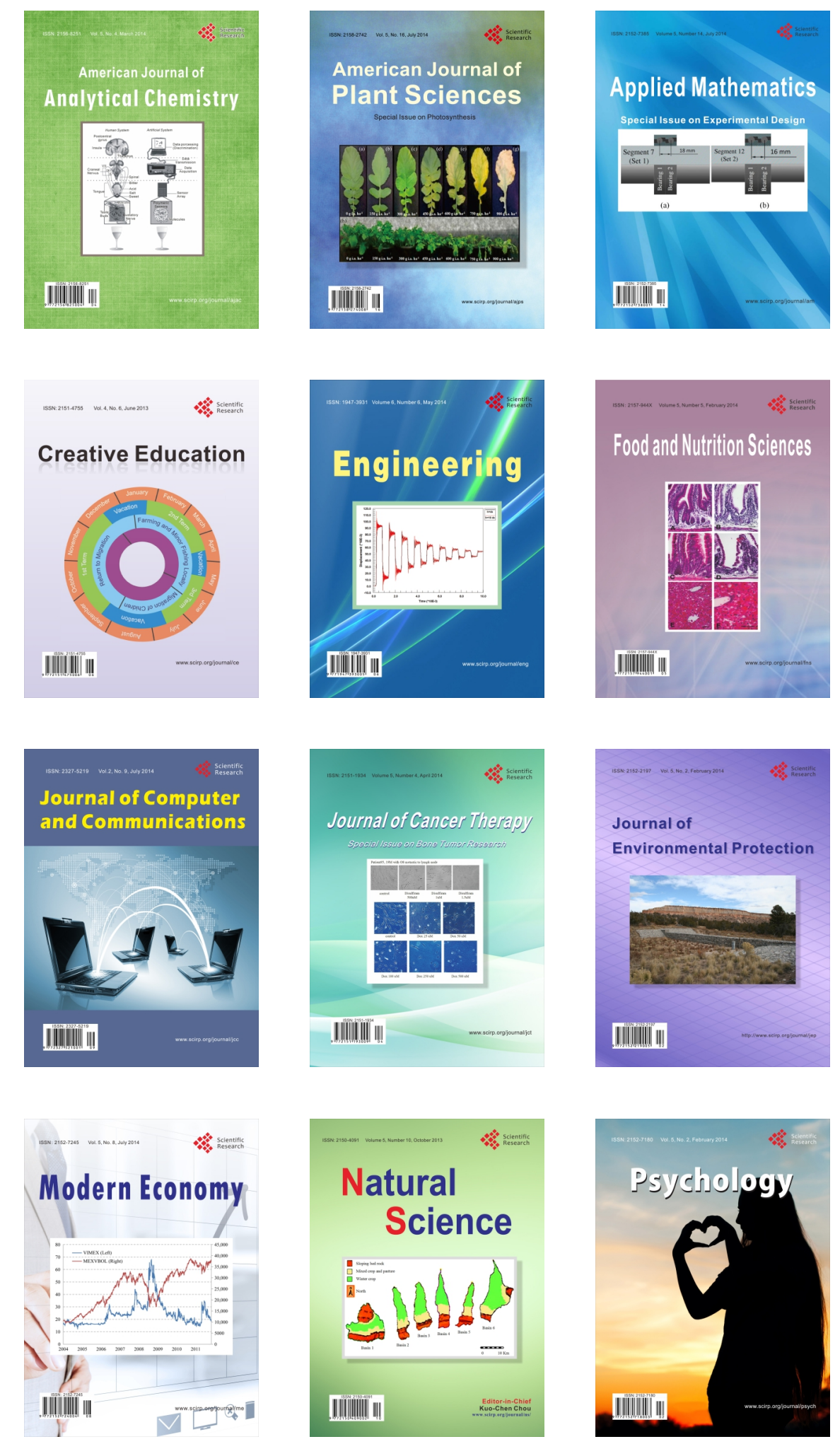